\title{
Teaching History in Transition at Forty Years
}

\author{
Stephen Kneeshaw \\ College of the Ozarks \\ Editor, Teaching History
}

I hate clichés. You know what I mean: those trite phrases that we use to make a point crystal clear or as plain as the nose on our face. We all fall victim and often step into a verbal trap that we had hoped to avoid. I often remind my students in "tips for writing" that they should avoid clichés like the plague. But sometimes old and trusted phrases work well for us. For me, this is one of those moments when clichés work, specifically "it ain't over till it's over," "every dark cloud has a silver lining," and "we are all in this together."

Here late in 2015, as we put the finishing touches on the fall issue in Volume 40 of Teaching History, which will be my final issue as Editor, I look back with great pride on the times and the people and the places that this professional adventure has taken me. "Oh, the places you'll go!" to quote from Dr. Seuss is a line that comes to mind. When the late Philip Rulon of Northern Arizona and Loren Pennington of Emporia State University asked me in the spring of 1974 to join them in founding a new journal in history education, I jumped to accept the kind of challenge that seldom comes to a 20 -something historian and teacher. But I was young and eager and confident that I could do the work of editing Teaching History: A Journal of Methods. I knew from that first moment that I would have great counsel and support from Phil and Loren. ${ }^{1}$

Together, we three founders created a larger team, starting in the spring of 1975 , taking slow but carefully measured steps, convinced (in our hearts if not our heads) that this venture - to start and build a professional journal that could make a difference in the lives and careers of other teaching historians just like us-could succeed and survive in a tough journal world. In that first year, we brought together eleven young men and women with promise: To start, Ronald Butchart then at SUNY Cortland agreed to be our first book review editor, and he quickly became my "number two" on the editorial team and a good friend to this day. Marsha Frey of Kansas State University and Bullitt Lowry of the University of North Texas, among others, also said "yes" to our invitations to join the team. To add some experience, Phil Rulon agreed to serve on the Board of Editors, a spot he held for almost four decades until his untimely passing in 2014. Loren Pennington volunteered to direct the journal's

\footnotetext{
'For some thoughts about the early days of the journal, see Stephen Kneeshaw, "A History of Teaching History" and "Crisis in the Classroom, or Clio Down But Not Out," Teaching History, 1 (Spring 1976), 1-5, and Stephen Kneeshaw, "Teaching History after Five Years," Teaching History, 6 (Spring 1981), $1-4$.
} 
subscription and publication efforts out of Emporia State where we have published Teaching History for all of these forty years.

As we moved through the late 1970 s and into the 1980 s, some of our original board members left the editorial and advisory teams, but we filled those slots and added more positions with other history educators whose work became critical to our continuing rise: William Mugleston of Albany Junior College, Raymond Hebert of Thomas More College, Donn Neal of the National Archives, and Calvin Allen, Jr., my colleague then at the College of the Ozarks, to name four of the newcomers, became key players as editorial readers and counselors for me. Mugleston succeeded Ron Butchart as book review editor at the six-year mark. Even as a fledgling journal, we attracted some big names in the history profession who published in Teaching History, including Darlene Clark Hine of Purdue University (later the president of the Organization of American Historians), Robert A. Divine of the University of Texas, and Don Wilson, the National Archivist of the United States. ${ }^{2}$ But most of the essays we reviewed and published came from enterprising young history educators with good ideas to share with our growing audience of teachers and subscribers. By our tenth year and then beyond, we knew that Teaching History had made a difference in our discipline. We had silenced any doubters who had expected Teaching History to fall as many professional start-up journals do in their first five to ten years. To quote the late great Yogi Berra: "It ain't over till it's over." There was no "over" for us. In fact, Teaching History was just getting started.

Through the 1980s and 1990s and eventually into a new century, the journal underwent some cosmetic changes, notably in cover design and coloration. More important changes took place behind the scenes. The editorial and advisory boards changed while growing in numbers; we brought some other rising history educators into "the TH gang," as we often called ourselves, while other members rotated off or left the TH boards when they retired from teaching. We also suffered some notable losses of good friends when Bullitt Lowry and Phil Rulon passed away after long illnesses. But the others of us continued to feel their spirit as we recommitted to do our best work in years still to come. And the journal grew in size, starting at 40 pages with the first issues in 1976, rising to 48 and then 56, and now Teaching History runs at 64 pages per issue, assuring our readers even more high quality ideas and insightful book reviews to aid them in their careers and classrooms.

Yet even in the midst of change, some things stayed constant. One person continuing for forty years as Editor ensured consistency in the quality and format of the journal's essay-over four decades, Teaching History has spoken in "one voice," if

'Darlene Clark Hine, "The Four Black History Movements: A Case for the Teaching of Black History," Teaching History, 5 (Fall 1980), 108-117; A. Divine, "Viewpoint-The Historian and the Nuclear Arms Race," Teaching History, 9 (Spring 1984), 33-36; Don Wilson, "Teaching for the Future by Reaching into the Past," Teaching History, 18 (Spring 2003), 3-13. 
you will. Emporia State University started as our home base in the mid-seventies and continues in that role in 2015. The management of publication at ESU has shifted hands from Loren Pennington to Sam Dicks to Chris Lovett, but their dedication to Teaching History never wavered. We also have enjoyed top-quality work from our administrative specialist at ESU, Jacque Fehr, who prepares copy in the critical stages between editorial work and publication. As Editor, I have been blessed with a team that always has worked well together. Sometimes the names changed on the editorial and advisory boards, but one after another gave me good counsel when I sought out their advice, met deadlines that I set for them, and provided thoughtful commentary and recommendations on essays and book reviews under consideration for publication. The Book Review Editors--from Ron Butchart in the beginning to Bill Mugleston and Robert Page, both at Georgia Highlands College, to David Dalton of College of the Ozarks today-have always maintained an efficient and effective operation that made my work as editor easier to manage. And over forty years, we have stayed faithful to our original mission, set by the founders in 1975 : “...to provide history teachers at all levels with the best and newest teaching ideas for their classrooms." Working closely together, for four decades "the TH gang" has turned out a journal in the spring and fall of each year that I would stand alongside any other history education journal to measure its quality and impact on our profession. We worked well as a team because we never forgot that "we are all in this together."

Where do we go from here? For Teaching History, I would go back to the old line and say with confidence that "It ain't over till it's over." Maybe I could add another one: "Our best days are still ahead." But for my run as Editor, the "over" has arrived. Fifteen years ago, as I reflected on Teaching History at twenty-five years in its journal life, I noted that "In the journal world, twenty-five years can be an eternity." We already had outlived most journals in history or any other discipline, but I predicted then that "Over the next several years surely Teaching History will continue to evolve." And I could have added that I expected the journal to continue to grow and to prosper. All came true ... But times change and over time we all face transitions in our lives: That moment has come.

Maybe five years ago or so, I started to think about days and years to come for Teaching History and for me as Editor. I asked myself how much longer I wanted to teach before retirement without any specific answer in mind. But I also started to think beyond my classroom days and about the changes that would come for Teaching History. What new changes might come for the journal? I thought about transitions approaching for the journal and about changes in the leadership of Teaching History that surely would happen. But questions still remained: When? and Who?

${ }^{3}$ Stephen Kneeshaw, "Teaching History at Twenty-Five Years," Teaching History, 25 (Spring 2000), $3-5$. 
The "who" came to me more quickly than the "when." I first "met" Sarah Drake Brown in the late 1990s when she submitted a manuscript to Teaching History. Her writing skills and her insight into teaching and learning, already evident in her as a rising history educator (actually a graduate student at that time), caught my attention. We published that essay in the fall of $1998 .{ }^{4}$ She published a second essay with us fifteen years later. ${ }^{5}$ In short order, I invited her to join "the TH gang" as a member of the Board of Editors in which role her recommendations and comments on essays under publication consideration always stood out as some of the best reviews I received. After tracking her work for a time and then following good counsel from several other board members, I asked Sarah to step up to become my Assistant Editor, in effect to become the editor-elect of Teaching History. She never hesitated: "I would be honored." That conversation over lunch during the meeting of NCHE (National Council for History Education) in Albuquerque in the spring of 2014 helped me decide that the time was right for Teaching History to move forward with a new generation of leaders. At one point, I had wondered if "dark clouds" might hover above Teaching History when I decided to step down from the editorship: Would we find a new Editor who would maintain a high level of performance for the journal? Not to worry: I am confident that Sarah Drake Brown is the "silver lining" whose move to Editor assures me that we will continue to move ahead in the journal world.

In another companion change near the top of our leadership team, this fall 2015 issue that closes volume year forty marks a change in Book Review Editor for Teaching History. My good colleague, David Dalton, who stepped into the role of BRE two years ago when the book review position was in flux, has taken on some new challenges at College of the Ozarks and cannot continue as Book Review Editor. He will move back to the Board of Editors. At the turn of the year, we will transfer this position to Richard Hughes of Illinois State University, who has been serving recently on the Board of Editors. Sarah and Richard already enjoy a close working professional relationship in history education circles that should guarantee a seamless shift from one pair (Kneeshaw and Dalton) to another (Brown and Hughes) in the lead positions for Teaching History.

Over many years, one of the hallmarks of Teaching History has been the close connections we have developed and friendships we have enjoyed within "the TH gang." We do things together, making decisions for or against accepting essays to publish (I often rely on suggestions from my editorial readers), proposing and presenting sessions sponsored by Teaching History at professional conferences, preparing new issues for

\footnotetext{
${ }^{4}$ Sarah E. Drake, "One Teacher's Experiences with Student Portfolios," Teaching History, 23 (Fall 1998), 60-76.

${ }^{3}$ Sarah Drake Brown, "A Systematic Use of Oral Histories to Promote Historical Thinking: Historical Thinking and the Iraq War," Teaching History, 38 (Fall 2013), 66-73.
} 
publication every spring and fall, and more. In that tradition of banding together, four of my closest friends and longtime members of the Board of Editors will retire from Teaching History with me. All but one of them already have retired from teaching and administration, but at my request they stayed active with the journal until this moment now at hand. Ronald Butchart of the University of Georgia, Marsha Frey of Kansas State, Calvin Allen, Jr., of Shenandoah University (once a history colleague at College of the Ozarks), and Roger Malfait of North Kitsap High School in Washington (a friend since our college days together) will join me in retirement from the journal as we close out this fortieth year of Teaching History. ${ }^{6}$ Over many years, they all have given the journal great service and me great counsel as we built up Teaching History from a good idea to become reality. To them and to all of the other men and women who have worked with me for so many years, I say "thank you."

Teaching History also stands out in quality for its corps of authors, reviewers, and readers who make the work of Editors and Book Review Editors a pleasurable part of our professional careers. Our authors have run a wide spectrum of academic interests and levels, but almost to a one they have worked closely and graciously with me as Editor, accepting suggestions for revisions without much hesitation and making changes within the time frames that I have suggested. Book reviewers also have met deadlines set by the BRE, helping us stay on schedule for publication in the spring and fall.

No professional journal can survive without an audience of readers and subscribers who appreciate the time and energy that our leadership and editorial teams commit to Teaching History. We have given our readers old standards for their classrooms - two examples come quickly to mind: the continuing value of the lecture method and the power of films to illustrate key points we want to make in our classrooms. But we also have stepped into new territories as times and technologies change-for example, essays on both board and electronic gaming in the classroom have appeared in the journal as has discussion of online instruction. As evidence, this fall 2016 issue will deliver some new and some traditional thoughts about teaching in history. ${ }^{7}$ To all of these groups who have contributed to Teaching History, we also extend our gratitude and our promise to continue to do our best work for you.

Finally, it is time for my "over ... and out!" On January 1, 2016, Teaching History will experience the biggest changes in its history. Sarah Drake Brown of Ball State will take the lead as Editor and Richard Hughes of Illinois State will become Book Review Editor. I have great confidence that under their direction Teaching

\footnotetext{
${ }^{6}$ Butchart, Frey, and I are the last three of the original start-up group for Teaching History. It seems fitting that we all should retire from the journal together.
}

${ }^{7}$ To see the full list of essays we have published over four decades, check out our website at http://www.emporia.edu/ teaching-history/. 
History will continue to thrive and prosper. For me, this is a bittersweet moment to see "my baby" enter a new stage of life. But I am proud to say "welcome" to Sarah and Richard and "thank you" to all of you who have played a part in this greatest adventure of my professional career!

$* * * * * * * * * * * * * *$

Editor of Teaching History (effective January 1, 2016)

Sarah Drake Brown

Department of History

Ball State University

Muncie, $\mathbb{N} 47306$

(765) 285-8700

Email: sedrakebrown@bsu.edu

Book Review Editor of Teaching History (effective January 1, 2016)

\author{
Richard Hughes \\ Department of History \\ Illinois State University \\ CB \#4420 \\ Normal, IL 61790-4420 \\ (309) 438-5424 \\ FAX: (309) 438-5607 \\ E-mail: rhughes@ilstu.edu
}

$* * * * * * * * * * * * *$

To contact Stephen Kneeshaw as Editor Emeritus (effective January 1, 2016), use email kneeshaws@msn.com. 